\title{
PENGARUH FIXED ASSET TURN OVER DAN CURRENT RATIO TERHADAP ROA PADA SUB SEKTOR SEMEN YANG TERDAFTAR DI BEI PERIODE 2015-2019
}

\author{
Indra Firmansyah, Muhammad Yusuf Syarifudin \\ D4 Akuntansi Keuangan, Politeknik Pos Indonesia Bandung \\ indrafirmansyah@poltekpos.ac.id, muhammadyusufsyarifudin@gmail.com
}

\begin{abstract}
ABSTRAK
Perusahaan mempunyai tujuan untuk memperoleh keuntungan sebanyak-banyaknya yang dijadikan tuntutan agar perusahaan dapat menjaga kelangsungan hidup perusahaan dan berupaya mengembangkan usahanya seiring berkembangnya zaman. Analisis rasio keuangan dilakukan untuk menilai kinerja perusahaan dalam mewujudkan tujuannya. Penelitian ini bertujuan untuk menguji pengaruh fixed asset turn over dan current ratio terhadap return on asset. Penelitian ini dilakukan pada Perusahaan sub sektor semen yang terdaftar di BEI. Metode yang digunakan dalam penelitian ini adalah metode kuantitatif dengan jenis perumusan masalah asosiatif bentuk hubungan kausal. Penelitian ini menggunakan data sekunder berupa laporan keuangan Sub sektor semen yang tedaftar di BEI dan pengambilan sampel dilakukan menggunakan metode nonprobability sampling dengan teknik sampling purposive. Teknik analisis data yang digunakan dalam penelitian ini adalah uji normalitas, korelasi product moment, korelasi berganda, regresi linier berganda, koefisien determinasi, uji t dan uji F. Hasil penelitian menunjukkan bahwa secara parsial fixed asset turn over tidak berpengaruh terhadap variabel return on asset. Dan terdapat pengaruh yang signifikan antara current ratio terhadap return on asset. Secara simultan terdapat pengaruh yang signifikan antara fixed asset turn over dan current ratio terhadap return on asset.
\end{abstract}

Kata kunci: Fixed Asset Turn Over, Current Ratio, dan Return On Asset

\begin{abstract}
The company has the goal of obtaining as much profit as possible which is used as a demand so that the company can maintain the survival of the company and strive to develop its business as the times develop. Financial ratio analysis is conducted to assess the company's performance in realizing its goals. This study aims to examine the effect of fixed asset turnover and current ratio to return on assets. This research was conducted at cement sub-sector companies listed on the IDX. The method used in this study is a quantitative method with the formulation of an associative problem in the form of a causal relationship. This study uses secondary data in the form of financial reports of cement subsectors listed on the IDX and the sampling is carried out using nonprobability sampling method with purposive sampling technique. The data analysis technique used in this study is the normality test, product moment correlation, multiple correlation, multiple linear regression, coefficient of determination, $t$ test and f test. The results showed that partially fixed asset turnover had no effect on the return on assets variable. And there is a significant influence between the current ratio on return on assets. Simultaneously, there is a significant influence between fixed asset turnover and current ratio on return on assets Keyword: Fixed Asset Turn Over, Current Ratio, and Return On Asset PENDAHULUAN
\end{abstract}


Perkembangan bisnis di dunia usaha saat ini berkembang pesat sakibat dari kebutuhan manusia pada era globalisasi. Berbagai macam perusahaan di seluruh dunia didirikan demi memenuhi kebutuhan manusia dalam menjalankan kegiatannya sehari-hari. Dalam menjalankan kegiatan operasional perusahaan, pasti setiap perusahaan memiliki aset. Menurut (Hery, 2016:12) "Sumber daya ekonomi yang dimiliki oleh perusahaan dinamakan aset/harta/kekayaan". Aset selanjutnya akan digunakan / dimanfaatkan oleh perusahaan demi lancarnya kegiatan sehari-hari. Aset yang dipakai dalam mendukung jalannya kegiatan usaha suatu perusahaan tersebut kemudian dapat mendukung jalannya kegiatan perusahaan dalam memperoleh laba .

Tidak hanya aset, perusahaan juga memiliki hutang sebagai modal utama permulaan perusahaan dalam pengembangan dan operasional perusahaan demi tercapainya laba yang diinginkan perusahaan. Kewajiban (Hutang) merupakan salah satu cara untuk mendapat tambahan pendanaan dari pihak eksternal, dengan konsekuensi perusahaan adalah harus melakukan pembayaran utang dengan batasan waktu yang ditentukan (Lasrya \& Ningsih 2020). Sumber modal suatu perusahaan erat kaitannya dengan hutang. Kemampuan perusahaan dalam memperoleh laba tidak dapat terlepas dari sumber modal perusahaan dalam mengembangkan usahanya dan menghasilkan laba yang maksimal (A..A. G. Putri \& Supadmi, 2016).

Dalam mengukur dan mengetahui tingkat profitabilitas suatu perusahaan dapat digunakan oleh salah satu metode profitabilitas yaitu ROA, ROA merupakan rasio yang menunjukan berapa besar laba bersih diperoleh perusahaan bila di ukur dari nilai aset dengan membandingkan antara laba bersih dengan total aset. Semakin besar ROA akan menunjukan kinerja perusahaan yang semakin baik, karena tingkat pengembalian semakin besar.

Di Indonesia sendiri banyak perusahaan nasional dan multinasional yang kegiatan usahanya bergerak diberbagai bidang yang dapat digolongkan sebagai perusahaan yang mampu mengelola asetnya secara efektif sehingga dapat menghasilkan laba yang tinggi. Salah satunya Perusahaan yang tergolong kriteria tersebut adalah Sub Sektor Semen yang tergolong dalam perusahaan manufaktur industri dasar yang terdaftar di BEI. Industri semen merupakan salah satu penopang pembangunan ekonomi di Indonesia.

Berdasarkan berita yang dimuat dalam (Kontan.co.id - Jakarta) , dimana sebagian emiten semen mencatatkan penurunan laba bersih per kuartal I-2019. Salah satu nya terjadi pada PT Semen Indonesia Tbk (SMGR) membukukan penurunan laba bersih sebesar 34,9\% secara tahunan, dari Rp 411,55 miliar menjadi Rp 268,1 miliar. Begitu juga dengan 
laba bersih PT Semen Baturaja Tbk (SMBR) yang menurun 67,4\% secara yoy menjadi Rp 4 miliar Sejak tahun 2016-2019 perkembangan ROA perbankan dari tahun ke tahun masih mengalami fluktuasi. Berikut ini telah disajikan data mengenai perkembangan ROA pada tiga Sub Sektor Perbankan yang terdaftar di Bursa Efek Indonesia.

Sejak tahun 2015-2019 PT Semen Indonesia Tbk (SMGR) dan PT Semen Baturaja Tbk (SMBR) cenderung mengalami penurunan laba dari tahun ke tahunnya sehingga mengakibatkan penurunan juga pada ROAnya juga. Berikut ini disajikan Tabel 1.1 yang merupakan Return on Asset pada PT Semen Indonesia Tbk (SMGR) dan PT Semen Baturaja Tbk (SMBR) tahun 2015-2019.

Tabel 1

Data Perkembangan Return On Asset PT Semen Indonesia (SMGR) dan PT Semen Baturaja (SMBR) Tahun 2015-2019

\begin{tabular}{|l|r|r|r|r|r|}
\hline \multirow{2}{*}{\multicolumn{1}{|c|}{ Nama Perusahaan }} & \multicolumn{5}{|c|}{ Tahun } \\
\cline { 2 - 7 } & $\mathbf{2 0 1 5}$ & $\mathbf{2 0 1 6}$ & $\mathbf{2 0 1 7}$ & $\mathbf{2 0 1 8}$ & $\mathbf{2 0 1 9}$ \\
\hline PT. Semen Indonesia Tbk. & 11,86 & 10,25 & 4,17 & 6,03 & 2,97 \\
\hline PT. Semen Baturaja Tbk. & 10,83 & 5,93 & 2,89 & 1,37 & 0,59 \\
\hline
\end{tabular}

Sumber: www.idx.co.id, Data diolah (2020)

Dari data tabel 1 di atas, Return on Asset pada perusahaan PT Semen Indonesia Tbk (SMGR) dan PT Semen Baturaja Tbk (SMBR) tahun 2015-2019. Dapat terlihat jelas terjadinya Return on Asset yang cenderung mengalami penurunan.

Terdapat indikator-indikator yang dapat mempengaruhi tingkat ROA, dan diduga resiko adanya penurunan pada ROA ini yaitu indikator Fixed Asset Turn Over dan Current Ratio. Kurangnya keandalan seorang manajer dalam mengelola aset dan utang perusahaan sangat memungkinkan mempengaruhi laba sehingga mempengaruhi pula pada ROA. Menurut Kasmir (2016:184) "Fixed asset turn over (perputaran aset tetap) merupakan rasio yang digunakan untuk mengukur berapa kali dana yang ditanamkan dalam aktiva tetap berputar dalam satu periode." Semakin besar rasio tersebut menunjukan kondisi operasional perusahaan semakin baik karena hasil tersebut mecerminkan bahwa aset dimanfaatkan pada tingkat aktifitas operasional perusahaan yang mengakibatkan dana yang tertanam pada unsur aset seimbang. Selain mengukur tingkat efisiensi dan efektifitas perusahaan dalam memanfaatkan asetnya, perusahaan juga perlu mengukur seberapa likuidnya perusahaan. Pengukurannya dapat dilihat pada perhitungan rasio likuiditas untuk menggambarkan kemampuan perusahaan dalam memenuhi kewajiban jangka panjang. Salah satu jenis rasio likuiditas yang dapat mengukur kemampuan perusahaan dalam memenuhi kewajibannya adalah current ratio (rasio lancar). 
Rasio lancar atau (current ratio) merupakan rasio untuk mengukur kemampuan perusahaan dalam membayar kewajiban jangka pendek atau utang yang segera jatuh tempo pada saat ditagih secara keseluruhan Menurut Kasmir (2016:134). Perhitungan rasio lancar dilakukan dengan cara membandingkan antara total aktiva lancar dengan total utang lancar. Apabila rasio rendah, dapat dikatakan bahwa perusahaan kurang modal untuk membayar utang.

Adapun hal ini di perkuat dengan adanya Penelitian terdahulu yang dilakukan oleh Yanti \& Chandra (2019) melakukan penelitian tentang Pengaruh Pengaruh Current Ratio, DAR, TATO Dan Tangibility Terhadap Return On Asset Pada Perusahaan Manufaktur Yang Terdaftar Di BEI. Hasil penelitian menyimpulkan bahwa Current Ratio berpengaruh signifikan terhadap ROA. Sedangkan penelitian terdahulu yang dilakukan oleh Vincent dkk (2018) melakukan penelitian tentang Pengaruh Fixed Assets Turnover, Debt To Total Assets Ratio Dan Current Ratio Terhadap Return On Assets Pada Perusahaan Sub Sektor Crude Petrolum Dan Natural Production (Minyak Mentah Dan Gas Bumi) Yang Terdaftar Di Bursa Efek Indonesia Periode 2012-2017 Hasil penelitian menyimpulkan secara parsial fixed assets turn over, debt to total assets ratio ,current ratio tidak berpengaruh terhadap terhadap Return On Asset

Berdasarkan penjelasan latar belakang mengenai fenomena dan penelitian terdahulu di atas, penulis tertarik mengambil judul untuk penelitian yaitu, "PENGARUH FIXED ASSET TURN OVER DAN CURRENT RATIO TERHADAP RETURN ON ASSET PADA PERUSAHAAN MANUFAKTUR SUB SEKTOR SEMEN YANG TERDAFTAR DI BEI TAHUN 20152019".

Adapun Identifikasi masalah dalam penelitian ini yaitu :

1. Bagaimana pengaruh fixed asset turn over terhadap ROA pada perusahaan manufaktur sub sektor semen yang tercatat di BEI tahun 2015-2019?

2. Bagaimana pengaruh Current Ratio terhadap ROA pada perusahaan manufaktur sub sektor semen yang tercatat di BEI tahun 2015-2019?

3. Bagaimana pengaruh fixed asset turn over dan current ratio terhadap ROA pada perusahaan manufaktur sub sektor semen yang tercatat di BEI tahun 2015-2019? 


\section{KAJIAN PUSTAKA}

\section{Fixed Asset Turn Over}

Menurut Kasmir (2016:184) "Fixed Assets Turn Over merupakan rasio yang digunakan untuk mengukur berapa kali dana yang ditanamkan dalam aktiva tetap berputar dalam satu periode.”Rumus untuk mencari fixed assets turn over dapat digunakan sebagai berikut:

$$
\text { Fixed Assets Turn Over }=\frac{\text { Penjualan (Sales) }}{\text { Total Aset Tetap (Total Fixed Assets })}
$$

Rasio ini menunjukan produktifitas aset tetap dalam menghasilkan pendapatan. Perputaran yang tinggi pada rasio ini menunjukan bahwa fixed asset digunakan secara efisien dan jumlah penjualan yang dihasilkan hanya dengan menggunakan jumlah aset yang kecil.

\section{Current Ratio}

Rasio lancar atau (current ratio) merupakan rasio untuk mengukur kemampuan perusahaan dalam membayar kewajiban jangka pendek atau utang yang segera jatuh tempo pada saat ditagih secara keseluruhan Menurut Kasmir (2016:134). Current ratio dapat pula dikatakan sebagai bentuk untuk mengukur tingkat keamanan suatu perusahaan. Perhitungan rasio lancar dilakukan dengan cara membandingkan antara total aktiva lancar dengan total utang lancar.

$$
\text { Current Ratio }=\frac{\text { Aktiva Lancar (Current Assets) }}{\text { Utang lancar (Current Liabilities) }}
$$

Apabila rasio rendah, dapat dikatakan bahwa perusahaan kurang modal untuk membayar utang, sedangkan apabila pengukuran rasio tinggi, belum tentu kondisi perusahaan sedang baik. Hal ini dapat saja terjadi karena kas tidak digunakan sebaik mungkin

\section{Return On Asset}

Return on asset sering disebut sebagai economic profitability yang merupakan ukuran kemampuan perusahaan dalam menghasilkan keuntungan dengan semua aktiva yang dimiliki perusahaan Menurut Kariyoto (2017). Semakin tinggi hasil pengembalian atas aset berarti semakin tinggi pula jumlah laba bersih yang dihasilkan dari setiap rupiah dana yang tertanam dalam total aset. Sebaliknya, semakin rendah hasil pengembalian atas aset berarti semakin rendah pula jumlah laba bersih yang dihasilkan dari setiap rupiah dana 
yang tertanam dalam total aset (Hery, 2016). Menurut Hery (2016) rumus yang digunakan untuk menghitung hasil pengembalian atas aset adalah

$$
\text { Return On Asset }=\frac{\text { Laba Bersih }(E A T)}{\text { Totak Aset }(\text { Total Assets })}
$$

Berdasarkan teori di atas, maka terdapat hipotesis penelitian yaitu sebagai berikut:

$\mathrm{H}_{1} \quad$ Diduga terdapat pengaruh yang signifikan antara fixed asset turn over terhadap return on asset pada Sub Sektor semen yang terdaftar di BEI periode 2015-2019.

$\mathrm{H}_{2}$ Diduga terdapat pengaruh yang signifikan antara current ratio terhadap return on asset pada Sub Sektor Semen yang terdaftar di BEI periode 2015-2019.

$\mathrm{H}_{3} \quad$ Diduga terdapat pengaruh yang signifikan antara fixed asset turn over dan current ratio terhadap return on asset pada Sub Sektor Semen yang terdaftar di BEI periode 2015-2019.

\section{METODE PENELITIAN}

\section{Jenis Penelitian}

Penelitian ini menggunakan metode penelitian kuantitatif. Menurut Sugiyono (2017) "metode penelitian kuantitatif dapat diartikan sebagai metode penelitian yang berlandaskan pada filsafat positivisme, digunakan untuk meneliti pada populasi atau sampel tertentu, pengumpulan data menggunakan instrumen penelitian, analisis data bersifat kuantitatif / statistik, dengan tujuan untuk menguji hipotesis yang telah ditetapkan".

Berdasarkan identifikasi masalah yang sudah dikemukakan sebelumnya, peneliti menggunakan jenis rumusan masalah asosiatif yang berbentuk hubungan sebab akibat (kausal). Menurut Sugiyono (2017) "rumusan masalah asosiatif adalah suatu rumusan masalah penelitian yang bersifat menanyakan hubungan antara dua variabel atau lebih".

\section{Teknik Pengumpulan Data}

Menurut Sugiyono (2017) "teknik pengumpulan data merupakan langkah yang paling strategis dalam penelitian, karena tujuan utama dari penelitian adalah mendapatkan data. Tanpa mengetahui teknik pengumpulan data, maka peneliti tidak akan mendapatkan data yang memenuhi standar data yang ditetapkan. Pengumpulan data dapat dilakukan dalam berbagai setting, berbagai sumber, dan berbagai cara".

Berdasarkan sumbernya, penelitian ini menggunakan data sekunder. Menurut Sugiyono (2017) "sumber sekunder merupakan sumber yang tidak langsung memberikan data kepada pengumpul data, misalnya lewat orang lain atau lewat dokumen". Data yang digunakan dalam penelitian ini adalah data yang diambil dari dokumen berupa laporan 
keuangan sub sektor semen yang terdaftar di Bursa Efek Indonesia periode 2015-2019 yang diperoleh melalui website resmi www.idx.co.id.

\section{Teknik Sampling}

\section{Populasi}

Menurut Sugiyono (2017) populasi adalah wilayah generalisasi yang terdiri atas: obyek / subyek yang mempunyai kualitas dan karakteristik tertentu yang ditetapkan oleh peneliti untuk dipelajari dan kemudian ditarik kesimpulannya. Jadi populasi bukan hanya orang, tetapi juga obyek dan benda-benda alam yang lain. Populasi juga bukan sekedar jumlah yang ada pada obyek / subyek yang dipelajari, tetapi meliputi seluruh karakteristik / sifat yang dimiliki oleh subyek atau obyek itu . Populasi yang digunakan dalam penelitian ini adalah Laporan Keuangan Sub Sektor Semen yang terdaftar di Bursa Efek Indonesia dari awal berdiri sampai sekarang.

\section{Sampel}

Menurut Sugiyono (2017) sampel adalah bagian dari jumlah dan karakteristik yang dimiliki oleh populasi tersebut. Bila populasi besar, dan peneliti tidak mungkin mempelajari semua yang ada pada populasi, misalnya karena keterbatasan dana, tenaga dan waktu, maka peneliti dapat menggunakan sampel yang diambil dari populasi itu. Apa yang dipelajari dari sampel itu, kesimpulannya akan dapat diberlakukan untuk populasi. Untuk itu sampel yang diambil dari populasi harus betul-betul representatif (mewakili).

Dalam penelitian ini menggunakan teknik sampling nonprobability sampling dengan teknik sampling purposive. Menurut Sugiyono (2017) "nonprobability sampling adalah teknik pengambilan sampel yang tidak memberi peluang / kesempatan sama bagi setiap unsur atau anggota populasi untuk dipilih menjadi sampel". Sedangkan menurut Sugiyono (2017) "teknik sampling purposive adalah teknik penentuan sampel dengan pertimbangan tertentu". Penggunaan sampling purposive ditetapkan oleh peneliti dengan beberapa kriteria yang digunakan sampel yaitu

1. Laporan laba rugi dan neraca pada 6 perusahaan sub sektor semen yang terdaftar di Bursa Efek Indonesia selama periode 5 tahun terakhir dari (2015-2019)

2. Data penjualan dan total aset tetap pada 6 perusahaan sub sektor semen yang terdaftar di Bursa Efek Indonesia selama periode 2015-2019

3. Data total aktiva lancar dan utang lancar pada 6 perusahaan sub sektor semen yang terdaftar di Bursa Efek Indonesia selama periode 2015-2019

4. Data laba bersih dan total aset pada 6 perusahaan sub sektor semen yang terdaftar di Bursa Efek Indonesia selama periode 2015-2019 
Berdasarkan kriteria yang telah di sebutkan diatas, maka sampel yang memenuhi kriteria pada sub sektor semen pada tahun 2015-2019 yaitu laporan keuangan dari 6 perusahaan dengan tahun pengamatan selama 5 tahun, jadi jumlah data yang diperoleh yaitu 30 data.

\section{Teknik Analisis Data}

Teknik analisis yang digunakan dalam penelitian ini yaitu teknik analisis kuantitatif. Karena data nya berupa angka-angka, yakni untuk menguji pengaruh variabel fixed asset turn over terhadap return on asset dan current ratio terhadap return on asset. Untuk menganalisis masalah dan pengolahan data yang diperoleh agar penelitian ini dapat membuktikan hipotesis yang ada, maka penelitian ini akan dibantu dengan menggunakan aplikasi SPSS versi 25.0 agar data yang dihasilkan lebih akurat.

Teknik analisis data yang digunakan dalam penelitian ini yaitu uji normalitas, analisis korelasi product moment, analisis korelasi berganda, analisis regresi linier berganda, analisis koefisien determinasi, uji t dan uji $\mathrm{F}$.

\section{HASIL PENELITIAN DAN PEMBAHASAN}

\section{Uji Normalitas}

Uji Normalitas ini digunakan untuk mengetahui apakah data yang diperoleh terdistribusi normal atau tidak. Berikut ini adalah hasil dari korelasi product moment dengan menggunakan aplikasi SPSS versi 25.0 yaitu:

\section{Tabel 2}

\section{Hasil Uji Normalitas}

\begin{tabular}{|c|c|c|}
\hline \multicolumn{3}{|c|}{ One-Sample Kolmogorov-Smirnov Test } \\
\hline & & $\begin{array}{c}\text { Unstandardized } \\
\text { Residual }\end{array}$ \\
\hline $\mathbf{N}$ & & 30 \\
\hline \multirow[t]{2}{*}{ Normal Parameters ${ }^{0.0}$} & Mean & .0000000 \\
\hline & Std. Deviation & 2.86681790 \\
\hline \multirow[t]{3}{*}{ Most Extreme Differences } & Absolute & .158 \\
\hline & Positive & .158 \\
\hline & Negative & -.098 \\
\hline Test Statistic & & .158 \\
\hline Asymp. Sig - (2-tailed) & & $.053^{\circ}$ \\
\hline
\end{tabular}

Berdasarkan hasil pengolahan data dengan menggunakan program SPPS, dapat diketahui bahwa nilai uji normalitas menggunakan uji Kolmogorov smirnov test menunjukkan sebesar 0,053 , hal ini berarti bahwa data yang digunakan dalam penelitian ini data nya berdistribusi normal karena nilai probabilitas $>0,05$, yaitu $0,053>0,05$ bahwa data berdistribusi normal. 


\section{Analisis Korelasi Product Moment}

Analisis ini digunakan untuk mengetahui hubungan antara satu variabel independen terhadap satu variabel dependen. Berikut ini adalah hasil dari korelasi product moment dengan menggunakan aplikasi SPSS versi 25.0 yaitu:

Tabel 3

Hasil Analisis Korelasi Product Moment

\begin{tabular}{|c|c|c|c|c|}
\hline \multicolumn{5}{|c|}{ Correlations } \\
\hline & & FATO & $\mathrm{CR}$ & ROA \\
\hline \multirow[t]{3}{*}{ FATO } & Pearson Correlation & 1 & -.005 & .241 \\
\hline & Sig- (2-tailed) & & .977 & 199 \\
\hline & $\mathbf{N}$ & 30 & 30 & 30 \\
\hline \multirow[t]{3}{*}{ CR } & Pearson Correlation & -.005 & 1 & $-549^{-}$ \\
\hline & Sig. (2-tailed) & -977 & & .002 \\
\hline & $\mathbf{N}$ & 30 & 30 & 30 \\
\hline \multirow[t]{3}{*}{ ROA } & Pearson Correlation & 241 & $.549^{--}$ & 1 \\
\hline & Sig. (2-tailed) & -199 & .002 & \\
\hline & $\mathbf{N}$ & 30 & 30 & 30 \\
\hline
\end{tabular}

Sumber: Output SPSS, data diolah (2020)

Dari hasil pengolahan data dengan menggunakan SPSS versi 25, serta diukur dan dilihat tingkat hubungan dengan pedoman Interprestasi koefisien korelasi bahwa menunjukkan koefisien korelasi antara variabel FATO (X1) terhadap ROA (Y) menghasilkan nilai $\mathrm{r}$ nya sebesar 0,241 yang mempunyai nilai koefisien korelasi berada pada interval 0,20-0,399 yaitu memiliki tingkat hubungan yang rendah. Sedangkan untuk variabel CR (X2) terhadap ROA (Y) menghasilkan nilai $r$ nya sebesar 0,549 yang mempunyai nilai koefisien korelasi berada pada interval 0,40-0,599 yaitu memiliki tingkat hubungan yang sedang.

Jadi dapat disimpulkan bahwa terdapat hubungan yang rendah antara FATO (X1) terhadap ROA (Y) pada Perusahaan Sub Sektor Semen yang terdaftar di BEI periode 2015 - 2019 dimana menghasilkan nilai $r$ nya sebesar 0,241. Sementara itu terdapat hubungan yang sedang antara CR (X2) terhadap ROA (Y) yang mana menghasilkan nilai $r$ nya sebesar 0,549 .

\section{Analisis Korelasi Berganda}

Analisis ini digunakan untuk mengetahui secara bersama-sama hubungan antara dua atau lebih variabel independen terhadap variabel dependen. Berikut ini adalah hasil dari korelasi berganda dengan menggunakan aplikasi SPSS versi 25.0 yaitu:

Tabel 4

Hasil Analisis Korelasi Berganda 


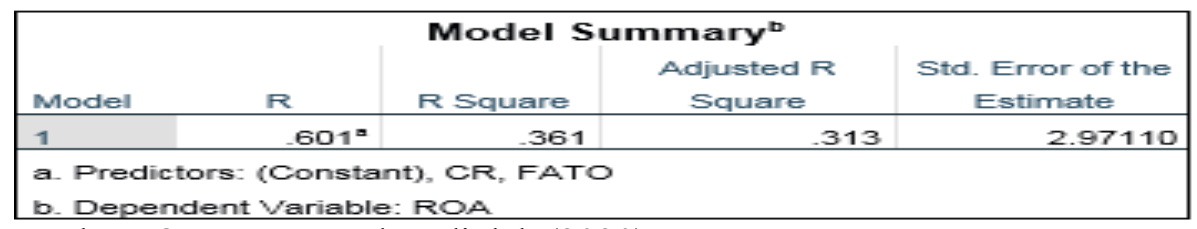

Sumber: Output SPSS, data diolah (2020)

Dari hasil pengolahan data dengan menggunakan SPSS versi 25, serta diukur dan dilihat tingkat hubungan dengan pedoman Interprestasi koefisien korelasi maka dapat diketahui pengaruh FATO dan CR terhadap ROA secara bersama-sama atau simultan dapat dilihat dari nilai $\mathrm{R}$ nya sebesar 0,601 yang menunjukkan bahwa nilai koefisien korelasi berada pada interval 0,60-0,799 yaitu memiliki tingkat hubungan yang kuat. Berdasarkan uraian diatas dapat disimpulkan bahwa terdapat hubungan yang kuat antara FATO dan CR terhadap ROA pada Perusahaan Sub Sektor Semen periode 2015-2019.

\section{Analisis Regresi Linier Berganda}

Analisis ini dilakukan untuk mengetahui hubungan antara variabel-variabel independen dengan variabel dependen, apakah masing-masing variabel independen mempunyai hubungan positif atau negatif serta untuk memprediksi nilai dan variabel dependen apakah variabel dependen nya mengalami kenaikan atau penurunan apabila nilai variabel independen nya di naik atau diturunkan. Berikut ini adalah hasil dari regresi linier berganda dengan menggunakan aplikasi SPSS versi 25.0 yaitu:

\section{Tabel 5}

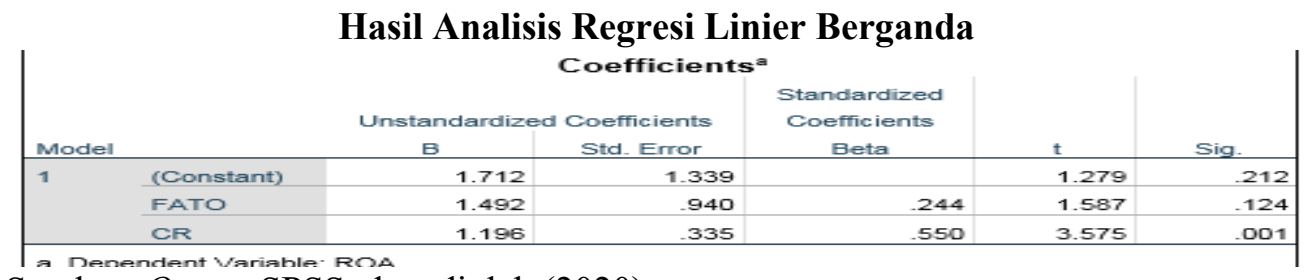

Sumber: Output SPSS, data diolah (2020)

Dapat dilihat dari hasil pengolahan data diatas, maka terdapat persamaan sebagai berikut:

$$
\mathrm{Y}=1,712+1,492 \mathrm{X}_{1}+1,196 \mathrm{X}_{2}
$$

Dari persamaan diatas, dapat dijelaskan sebagai berikut:

1. Jika variabel FATO $\left(\mathrm{X}_{1}\right)$ dan $\mathrm{CR}\left(\mathrm{X}_{2}\right)$ nilainya adalah 0 , maka nilai variabel return on asset $(\mathrm{Y})$ adalah sebesar konstanta atau sebesar 1,712

2. Hasil koefisien regresi variabel FATO $\left(\mathrm{X}_{1}\right)$ yaitu sebesar 1,492 , artinya jika variabel independen lain nilainya tetap dan FATO mengalami kenaikan sebesar 1 persen maka variabel dependen return on asset (Y) akan mengalami kenaikan sebesar 1,492. Karena koefisien $X_{1}$ bernilai positif, maka terdapat hubungan yang 
positif juga antara FATO $\left(\mathrm{X}_{1}\right)$ terhadap return on asset $(\mathrm{Y})$, jadi kenaikan FATO $\left(\mathrm{X}_{1}\right)$ mengakibatkan kenaikan return on asset $(\mathrm{Y})$.

3. Hasil koefisien regresi variabel $\mathrm{CR}\left(\mathrm{X}_{2}\right)$ yaitu sebesar 1,196, artinya jika variabel independen lain nilainya tetap dan CR mengalami kenaikan sebesar 1 persen maka variabel dependen return on asset (Y) akan mengalami kenaikan sebesar 1,196. Karena koefisien $\mathrm{X}_{2}$ bernilai positif, maka terdapat hubungan yang positif juga antara $\mathrm{CR}\left(\mathrm{X}_{2}\right)$ terhadap return on asset $(\mathrm{Y})$, jadi kenaikan $\mathrm{CR}\left(\mathrm{X}_{2}\right)$ mengakibatkan kenaikan return on asset $(\mathrm{Y})$

\section{Analisis Koefisien Determinasi}

Koefisien determinasi digunakan untuk mengetahui besarnya presentase pengaruh variabel independen terhadap variabel dependen. Berikut ini adalah hasil dari koefisien determinasi dengan menggunakan aplikasi SPSS versi 25.0 yaitu:

\section{Tabel 6}

Hasil Analisis Koefisien Determinasi

\begin{tabular}{|c|c|c|c|c|}
\hline \multicolumn{5}{|c|}{ Model Summary } \\
\hline Model & $\mathbf{R}$ & $\mathrm{R}$ Square & $\begin{array}{l}\text { Adjusted R } \\
\text { Square }\end{array}$ & $\begin{array}{l}\text { Std. Error of the } \\
\text { Estimate }\end{array}$ \\
\hline 1 & $601^{\prime}$ & 361 & .313 & 2.97110 \\
\hline
\end{tabular}

Dari hasil pengolahan data diatas, dapat diketahui bahwa nilai $R^{2}$ yaitu sebesar 0,361 artinya presentase sumbangan pengaruh variabel FATO $\left(\mathrm{X}_{1}\right)$ dan $\mathrm{CR}\left(\mathrm{X}_{2}\right)$ terhadap variabel return on asset $(\mathrm{Y})$ sebesar 36,1\%, sedangkan sisanya 63,9\% dipengaruhi oleh faktor lain yang tidak dimasukkan pada penelitian ini.

\section{Pengujian Hipotesis}

\section{Uji t}

Uji t digunakan untuk menguji hipotesis secara parsial atau masing-masing antara satu variabel independen terhadap satu variabel dependen. Berikut ini adalah hasil dari perhitungan uji t dengan menggunakan aplikasi SPSS versi 25.0 yaitu:

\begin{tabular}{|c|c|c|c|c|c|c|}
\hline \multicolumn{7}{|c|}{$\begin{array}{c}\text { Tabel } 7 \\
\text { Hasil Uji t }\end{array}$} \\
\hline \multicolumn{7}{|c|}{ Coefficients $^{a}$} \\
\hline & & \multicolumn{2}{|c|}{ Unstandardized Coefficients } & \multirow{2}{*}{$\begin{array}{c}\text { Standardized } \\
\text { Coefficients } \\
\text { Beta }\end{array}$} & \multirow[b]{2}{*}{$T$} & \multirow[b]{2}{*}{ Sig. } \\
\hline Model & & B & Std. Error & & & \\
\hline \multirow[t]{3}{*}{1} & (Constant) & 1.712 & 1.339 & & 1.279 & .212 \\
\hline & FATO & 1.492 & .940 & .244 & 1.587 & .124 \\
\hline & CR & 1.196 & 335 & .550 & 3.575 & .001 \\
\hline
\end{tabular}

Sumber: Output SPSS, data diolah (2020)

1. Pengujian hipotesis variabel FATO $\left(\mathrm{X}_{1}\right)$ terhadap variabel return on asset $(\mathrm{Y})$ 
Hasil pengujian FATO terhadap return on asset menunjukkan $t_{\text {hitung }}$ diperoleh sebesar 1,587 dan signifikansi 0,124 dan untuk $t_{\text {tabel }}$ dapat dilihat pada tabel statistik. Pada signifikansi 0,05 dengan derajat kebebasan $\mathrm{dk}$ pembilang $=2$, dk penyebut $=27(\mathrm{n}-\mathrm{k}-1)$, dimana $n=j u m l a h$ data, $k=j u m l a h$ variabel $x$, hasil diperoleh untuk $t_{\text {tabel }}$ sebesar 2,052 . Nilai $\mathrm{t}_{\text {hitung }}<\mathrm{t}_{\text {tabel }}(1,587<2,052)$ dan signifikansi $>0,05(0,124>0,05)$ maka $\mathrm{Ho}_{1}$ diterima dan $\mathrm{Ha}_{1}$ ditolak. Dapat dilihat bahwa perhitungan uji secara parsial variabel fixed asset turn over mempunyai thitung sebesar 1,587 dan ttabel sebesar 2,052 yang berarti thitung $<$ ttabel dan angka signifikansi sebesar 0,124 yang berada di atas signifikansi 0,05. Maka dapat disimpulkan bahwa hipotesis Ha1 ditolak dan Ho1 diterima, berarti secara parsial tidak terdapat pengaruh yang signifikan antara variabel fixed asset turn over terhadap variabel return on asset pada Perusahaan Sub Sektor Semen Periode 2015 - 2019.

2. Pengujian hipotesis variabel $\mathrm{CR}\left(\mathrm{X}_{2}\right)$ terhadap variabel return on asset $(\mathrm{Y})$

Hasil pengujian CR terhadap return on asset menunjukkan $t_{\text {hitung }}$ diperoleh sebesar 3,575 dan signifikansi 0,001 , dan untuk tabel dapat dilihat pada tabel statistik. Pada signifikansi 0,05 dengan derajat kebebasan $\mathrm{dk}$ pembilang $=2$, dk penyebut $=27(\mathrm{n}-\mathrm{k}-1)$, dimana $\mathrm{n}=$ jumlah data, $\mathrm{k}=$ jumlah variabel $\mathrm{x}$, hasil diperoleh untuk $\mathrm{t}_{\text {tabel }}$ sebesar 2,052. Nilai $\mathrm{t}_{\text {hitung }}>$ $\mathrm{t}_{\text {tabel }}(3,575>2,052)$ dan signifikansi $<0,05(0,001<0,05)$ maka $\mathrm{Ho}_{2}$ ditolak dan $\mathrm{Ha}_{2}$ diterima.Jadi, dapat disimpulkan bahwa CR secara parsial atau masing-masing terdapat pengaruh yang signifikan terhadap return on asset. Dapat dilihat bahwa perhitungan nilai

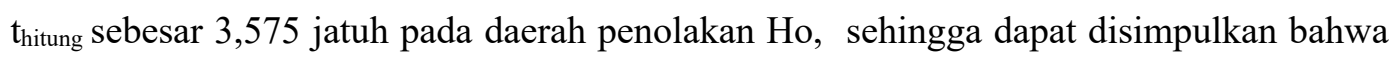
secara parsial terdapat pengaruh yang signifikan antara variabel CR terhadap return on asset.

\section{Uji F}

Uji F digunakan untuk mengetahui apakah dua atau lebih variabel independen secara bersama-sama berpengaruh signifikan terhadap variabel dependen. Berikut ini adalah hasil dari perhitungan uji F dengan menggunakan aplikasi SPSS versi 25.0 yaitu:

Tabel 8

Hasil Uji F

\begin{tabular}{|c|c|c|c|c|c|c|}
\hline \multicolumn{7}{|c|}{ ANOVA ${ }^{a}$} \\
\hline Model & & Sum of Squares & Df & Mean Square & $\mathrm{F}$ & Sig. \\
\hline \multirow[t]{3}{*}{1} & Regression| & 134.517 & 2 & 67.258 & 7.619 & $.002^{\circ}$ \\
\hline & Residual & 238.341 & 27 & 8.827 & & \\
\hline & Total & 372.857 & 29 & & & \\
\hline
\end{tabular}

Sumber: Output SPSS, data diolah (2020)

Hasil pengujian secara simultan dapat diketahui bahwa dapat diperoleh $\mathrm{F}_{\text {hitung }}$ sebesar 7,619 dan nilai signifikansi sebesar 0,002. Dari tabel $\mathrm{F}$ untuk $\alpha=0,05 \mathrm{dan} \mathrm{dk}$ pembilang $=$ 
2, dk penyebut $=27(n-k-1)$, dimana $n=j u m l a h$ data, $\mathrm{k}=$ jumlah variabel $\mathrm{x}$, hasil diperoleh untuk $F_{\text {tabel }}$ sebesar 3,35. Karena $F_{\text {hitung }}>F_{\text {tabel }}(7,619>3,19)$ dan signifikansi $<0,05(0,002$ $<0,05)$ maka $\mathrm{Ho}_{3}$ ditolak dan $\mathrm{Ha}_{3}$ diterima. Jadi dapat disimpulkan bahwa FATO dan CR secara simultan terdapat pengaruh yang signifikan terhadap return on asset pada Perusahaan Sub sektor semen yang terdaftar di BEI periode 2015 - 2019

\section{Pembahasan Hasil Penelitian}

\section{Pengaruh Fixed Asset Turn Over Terhadap Return On Asset}

Dari hasil perhitungan uji secara parsial variabel fixed asset turn over mempunyai thitung sebesar 1,587 dan ttabel sebesar 2,052 yang berarti thitung < ttabel dan angka signifikansi sebesar 0,124 yang berada di atas signifikansi 0,05. Maka dapat disimpulkan bahwa hipotesis Ha1 ditolak dan Ho1 diterima, berarti secara parsial tidak terdapat pengaruh yang signifikan antara variabel fixed asset turn over terhadap variabel return on asset pada Perusahaan Sub Sektor Semen Periode 2015 - 2019. Hasil penelitian ini sejalan dengan hasil penelitian yang dilakukan oleh Vincent Dkk (2020), yang hasilnya menyatakan bahwa Secara parsial fixed assets turnover tidak berpengaruh terhadap Return On Asset. dan jika dikaitkan dengan teori Kasmir dimana menyatakan bahwa "faktor faktor yang mempengaruhi ROA selain dari fixed asset turn over (perputaran aset tetap) yaitu rasio likuiditas dimana rasio ini digunakan untuk mengukur kemampuan perusahaan dalam memenuhi kewajiban jangka pendeknya yang dihitung dengan membandingkan antara aktiva lancar dengan kewajiban lancar. Jadi dapat disimpulkan bahwa tidak hanya perputaran aset tetap yang mempengaruhi ROA namun ada faktor lain seperti kewajiban / utang.

\section{Pengaruh Current Ratio Terhadap Return On Asset}

Dari hasil perhitungan uji secara parsial variabel current ratio mempunyai thitung sebesar 3,575 dan ttabel sebesar 2,052 yang berarti thitung $>$ ttabel dan angka signifikansi sebesar 0,001 yang berada di bawah signifikansi 0,05. Maka dapat disimpulka bahwa hipotesis Ha2 diterima dan Ho2 ditolak. Jadi dapat disimpulkan bahwa CR secara parsial atau masing-masing terdapat pengaruh yang signifikan terhadap return on asset. Menurut Teori Kasmir "Rasio lancar atau (current ratio) merupakan rasio untuk mengukur kemampuan perusahaan dalam membayar kewajiban jangka pendek atau utang yang segera jatuh tempo pada saat ditagih secara keseluruhan". Perhitungan rasio lancar dilakukan dengan cara membandingkan antara total aktiva lancar dengan total utang lancar. Apabila rasio rendah, dapat dikatakan bahwa perusahaan kurang modal untuk membayar utang. 
Hasil penelitian ini sejalan dengan hasil penelitian yang dilakukan oleh Yanti \& Chandra (2019) dimana Hasil penelitian ini menunjukan Current Ratio berpengaruh signifikan terhadap ROA.

\section{Pengaruh Fixed Asset Turn Over dan Current Ratio Terhadap ROA}

Dari hasil perhitungan uji $\mathrm{F}$ dapat dilihat dari $\mathrm{F}_{\text {hitung }}$ sebesar 7,619 dan $\mathrm{F}_{\text {tabel }}$ sebesar 3,35 ini berarti $F_{\text {hitung }}>F_{\text {tabel }}$ dengan angka signifikansi 0,002 yang artinya lebih kecil dari 0,05. Maka dapat disimpulkan bahwa hipotesis $\mathrm{Ha}_{3}$ diterima dan $\mathrm{Ho}_{3}$ ditolak, artinya bahwa secara simultan terdapat pengaruh yang signifikan antara variabel Fixed Asset Turn Over dan current ratio terhadap return on asset pada Sub Sektor Semen periode 2015-2019. Menurut teori Kasmir bahwa FATO merupakan alat untuk mengukur tingkat efisiensi dan efektifitas perusahaan dalam pengembalian aset dalam satu periode sehingga mempunyai pengaruh terhadap ROA, selain FATO perusahaan perlu mengukur seberapa likuidnya perusahaan. Pengukurannya dapat dilihat pada perhitungan rasio likuiditas untuk menggambarkan kemampuan perusahaan dalam memenuhi kewajibannya. Salah satu jenis rasio likuiditas yang dapat mengukur kemampuan perusahaan dalam memenuhi kewajibannya adalah current ratio (rasio lancar). Hasil penelitian ini sejalan dengan hasil penelitian yang dilakukan oleh Endri Endri (2020) dimana Hasil penelitian ini menyatakan bahwa secara bersamaan CR, FATO, TATO, dan DER berpengaruh terhadap ROA pada Sub sektor farmasi yang tercatat di BEI periode $2014-2018$.

\section{KESIMPULAN DAN SARAN}

Berdasarkan hasil penelitian yang telah dilakukan, maka dapat ditarik kesimpulan sebagai berikut:

1. Berdasarkan hasil pengujian yang telah dilakukan menunjukan bahwa secara parsial tidak terdapat pengaruh yang signifikan antara variabel Fixed Asset Turn Over (X1) terhadap variabel Return On Asset (Y) pada Perusahaan Sub Sektor Semen yang terdaftar di BEI Periode 2015 - 2019

2. Berdasarkan hasil pengujian yang telah dilakukan menunjukan bahwa secara parsial terdapat pengaruh yang signifikan antara variabel Current Ratio (X2) terhadap variabel Return On Asset (Y) pada pada Perusahaan Sub Sektor Semen yang terdaftar di BEI Periode 2015 - 2019

3. Berdasarkan hasil pengujian yang telah dilakukan menunjukan bahwa secara simultan terdapat pengaruh yang signifikan antara variabel Fixed Asset Turn Over 
(X1) dan Current Ratio (X2) terhadap variabel Return On Asset (Y) pada Perusahaan Sub Sektor Semen yang terdaftar di BEI Periode 2015 - 2019.

Berdasarkan pembahasan dan kesimpulan pada penelitian ini, maka terdapat saran sebagai berikut:

1. Bagi perusahaan, diharapkan agar dapat mengelola aset serta kewajiban dengan baik lagi untuk kedepannya agar dapat memperoleh laba yang terus naik persentasenya dari tahun ke tahun.

2. Bagi peneliti selanjutnya, yang akan melakukan penelitian terkait dengan penelitian ini diharapkan untuk pengambilan sampel dapat diperluas, baik itu periode penelitian nya maupun jumlah sampel yang akan diteliti. Peneliti mengharapkan agar penelitian selanjutnya dapat menambahkan variabel independen (X) lain lagi selain FATO dan CR terhadap Return On Asset, misalnya dalam Rasio Aktivitas dapat diukur dengan menggunakan rasio perputaran piutang, rasio perputaran persediaan ataupun dalam mengukur rasio likuiditas seperti kas rasio dan kas rasio.

\section{DAFTAR PUSTAKA}

Endri Endri, L. S. (2020). Pengaruh CR, FATO, TATO, dan DER Terhadap ROA pada Sub Sektor Farmasi yang Tercatat di BEI Periode 2014-2018. Jurnal Farmasi.

Hery. (2016). Analisis Laporan Keuangan. PT Grasindo.

Kariyoto. (2017). Analisis Laporan Keuangan. Universitas Brawijaya Press.

Kasmir. (2017). Analisis Laporan Keuangan. PT Rajagrafindo Persada.

Lasrya, E., \& Ningsih, O. (2020). Analisis Faktor Faktor yang Mempengaruhi Persistensi Laba Pada Perusahaan Makanan dan Minuman yang Terdaftar di Bursa Efek Indonesia Periode 2013-2017. 1(1), 16-31.

Putri, A. . A. G., \& Supadmi, N. L. (2016). Penhgaruh Tingkat Hutang dan Kepemilikan Manajerial Terhadap Persistensi Laba Pada Perusahaan Manufaktur. 15, 915-942. Sugiyono. (2017). Metode Penelitian Kuantitatif, Kualiitatif, dan R\&D. CV Alfabeta. Sugiyono. (2017). Statistika Untuk Penelitian. CV Alfabeta.

Yanti, N. W., \& Chandra, S. (2019). Pengaruh Cr, Dar, Tato Dan Tangibility Terhadap Roa Pada Perusahaan manufaktur. Jurnal Akuntansi, Vol 3 No 1. 